Concept Paper

\title{
Wisdom for Traveling Far: Making Educational Travel Sustainable
}

\author{
Brack W. Hale
}

Environmental Studies, Franklin University Switzerland, 6924 Sorengo, Switzerland; bhale@fus.edu

Received: 15 April 2019; Accepted: 28 May 2019; Published: 30 May 2019

\begin{abstract}
Educational travel has been demonstrated to be an effective means of education to develop sustainable and pro-environmental behaviors. However, as this paper reviews, recent scholarship has revealed that educational travel may harm the communities that host it even while it is achieving gains for students. This paper encourages educational travel providers (institutions, staff, and faculty) to leverage the need for a broader perspective towards sustainability in educational travel programs so that their host communities also benefit. The programs can accomplish this by engaging students in the process of making the programs and their participants more sustainable. The paper ends with several examples from the author's own experience as an educational travel leader and several recommendations to reduce the negative impacts on host communities.
\end{abstract}

Keywords: educational travel; higher education; sustainability; experiential education; climate change; host communities

\section{Introduction}

Wits are needful for someone who travels widely ... Hávamál [1]

Educational travel programs, i.e. programs including field courses, study abroad, and semester exchanges where students have learning experiences in locations far from campus and typically abroad, have been shown to be effective learning environments where students develop sustainable and pro-environmental behaviors that extend beyond the programs (in some cases, well into their adult lives) regardless of the program's thematic focus [2-5]. The experience of traveling, living out of a suitcase, and being exposed to different cultures perhaps teaches participants to live more simply and efficiently, whether they go to China to study international business, Italy to study Renaissance art, or Tanzania to study savanna ecology. It comes then as no surprise that educational travel programs that focus on environmental issues and sustainability, such as a travel to Costa Rica to study conservation biology, also show better outcomes in the development of students' environmental and sustainable competencies than counterpart courses on home campuses [6-9]. As such, students who participate in educational travel, particularly in programs that encourage experiential learning and focus on sustainability or the environment, are better equipped to face the challenges of today and tomorrow.

Still, an important question that universities must ask is what cost do we incur by achieving these learning outcomes. As awareness of the impacts of climate change today and in the near future increases, there is a growing call to limit travel and to avoid travel that generates greenhouse gases: A Washington Post opinion piece pleas to the reader with its title: "for the love of the Earth, stop traveling" [10]; in Sweden, a movement is afoot to vacation by train rather than plane, inspired in part by the actions of a 16-year old Swede, Greta Thunberg, who famously travelled by train from Stockholm to the World Economic Forum in Davos in 2019 to demand action on climate change from world leaders [11]. Even in the academic literature, Dvorak et al. [12] discussed that one possible approach to dealing with educational travel's greenhouse gas emissions is to stop traveling (in the 
end, they opt for a less severe approach with a more intentional type of educational travel). However, Dvorak et al. were not wrong-in a world striving to prevent catastrophic climate change, educational travel that involves greenhouse gas emissions begs rationalization. Climate change aside, educational travel programs can also be intrusive in host communities and environments [13-15]. Thus, to make the benefits of educational travel sustainable for all stakeholders involved, program leaders and the universities or sponsoring organizations have to address the currently unsustainable aspects of their programs. In this paper, I briefly review the benefits of educational travel and the costs to the host destination and its resources. Then, reflecting on my own experiences and research, I explore ways to engage the student learning process in crafting more sustainable educational programs.

\section{A Brief Review of the Benefits of Educational Travel}

Educational travel programs hold great potential as vehicles for learning. According to Lutterman-Aguilar and Gingerich [16], educational travel goes hand in hand with experiential education, a recognized approach to teaching and learning. However, a travel with experiences is not in itself experiential education. The instructor or program staff needs to leverage experiences with time and space for reflection, analysis, and synthesis. Likely the results seen in the studies mentioned above [2-4] are due in part to program settings that engaged students in aspects of experiential learning. An intentionality behind experiential learning has since been echoed in multiple studies as an important driver of learning outcome achievement $[7,17,18]$. The educational experience can also be enhanced by incorporating active learning and student research, which were shown in a recent study to be the most effective high impact learning experiences in (US) undergraduate education [19]. The study abroad experience was also ranked as an effective high impact experience, primarily with respect to intercultural competencies outcomes. It stands to reason that combining these elements (experiential education, active learning, student research) in an educational travel program creates a powerful learning environment for pro-environmental and sustainability learning goals.

Many of the studies examining positive student outcomes from educational travel experiences discuss the experiences as experiential and transformative $[6,18,20]$. Often, existing studies are situated in the concept of global citizenship, which has become an important objective of many higher education institutions. Tarrant [18] posits that pro-environmental behaviors are part and parcel of global citizenship. His framework emphasizes the need for students to develop both awareness of environmental issues and their impacts as well as a sense of the ability to act to effect positive change. Thus, educational travel can be, in these circumstances, an important tool for universities to achieve the goal of creating global citizens. A synthesis of several studies that have used Tarrant's framework found significant gains in global citizenship, pro-environmental, and sustainability-related outcomes for students who study abroad [6]. Gains were particularly strong for students in programs that focused on sustainability themes. Although several of these studies focused on short-term experiences, Strange and Gibson [21] found that longer ( $>18$ days) educational travel programs can create transformative experiences with greater effects. Students in that study identified field trips, writing assignments, interactions with the local community, and self-reflection to be the more effective parts of the experience for them.

\section{The Elephant on the Plane: The Other Side of Educational Travel}

As a scholar of sustainability and a leader of educational travel programs, I have been interested in the sustainability (economic, environmental, and socio-cultural) of these programs, particularly with respect to host communities and environments. The research discussed in the last section demonstrates the positive impact educational travel programs can have on students' learning and particularly student knowledge of and engagement in sustainable practices. If these outcomes translate into better environmental citizens, the students' home regions and countries, as well at the globe as a whole, stand to benefit. However, these gains for students (and their home regions) should not come at the cost of distant communities and their environments. If they do, we are perhaps looking at a modern offshoot 
of colonial exploitation [22]. Carbon emissions from global travel affect the entire world, but certainly the impacts fall most heavily on people who often could not afford an international flight. Resource exploitation and societal disruptions in host environments may linger long after students have returned to their home countries. A literature review I completed with two colleagues situated educational travel within the realm of tourism and discussed how impacts are likely similar [15]. Educational travel programs often generate air pollution (most notably greenhouse gas emissions) in traveling to, from, and within their destinations. Once on-site, the programs and their participants consume local resources, produce waste, and may degrade local environments. Revenue from the program may or may not benefit the local community, depending on choices made for lodging, eating, and traveling around the area. Lastly, (larger) groups of students can be disruptive in local communities, introduce undesirable behaviors, and contribute to the exploitation of local cultures. The impacts however need not all be negative, as programs can bring important revenue to remote areas and can encourage conservation and other positive environmental behaviors. Ultimately, the kind and level of impacts depend upon logistical choices made by program leaders, individual decisions by students, and policies of the programs and local hosts, among others.

The carbon cost alone may be reason enough for us to question the sustainability of educational travel programs, regardless of future benefits for their participants. Recent reports speak of the urgent need to reduce carbon emissions and the level of greenhouse gases in the atmosphere [23,24]. Using data from 2018 Open Doors factsheets for regional educational travel to and from the US [25], I roughly estimated the total carbon dioxide emissions for these (undergraduate) students to be 2.5 million tonnes (Figure 1), which is greater than the carbon dioxide emissions of the lowest emitting 65 countries in 2014 [26] or the equivalent of approximately 150,000 US Americans (see Appendix A for full calculation methodology). It is important to note that these estimates only account for educational travel to and from the US and thus do not include programs like Erasmus in Europe. As such, they are a significant underestimate of actual total emissions due to educational travel.

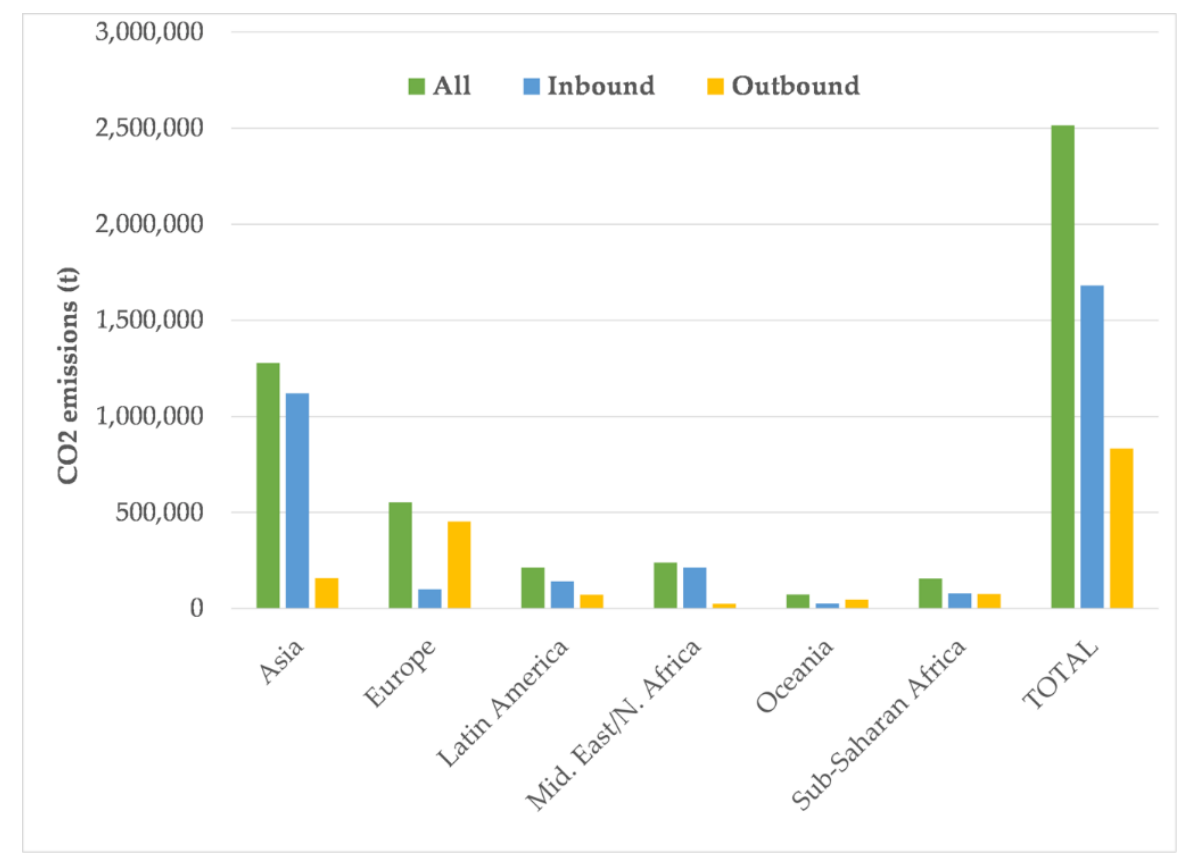

Figure 1. Estimated carbon emissions by region for students traveling to/from the US on undergraduate educational travel programs.

One could argue that the pro-environmental educational benefits serve as an offset for educational travel programs since they likely lead to more sustainable environmental behaviors for the participants and thus, similar to a purchased offset, might result in lower future emissions. Purchased carbon offsets generally invest money in activities that prevent emissions or remove carbon from the atmosphere 
such as investments in renewable energy, energy efficiency, or planting trees [27]. However, the timing of carbon reductions resulting from some purchased offsets can be problematic in a world where we need to reduce carbon emissions sooner rather than later. Gössling et al. [28] discuss how different assumptions about and approaches to planting trees for carbon sequestration determine the timeframe for the removal of carbon from the atmosphere, which can mean full compensation of a flight's emissions might take decades. Likewise, a student who makes small changes in their lifestyle after an educational travel program might require years to decades before they have offset their emissions from said travel. Both of these approaches, albeit well intended, do not result in rapid enough changes to represent a viable solution for emissions from educational travel programs.

An argument could also be made that, in certain situations, students actually decrease their carbon footprints on educational travel programs. Studies of the tourism industry have found that some tourists from areas with high ecological footprints may actually experience a reduction in their own ecological footprint when traveling to and spending sufficient amounts of time in an area with a lower ecological footprint [29-31]. For example, Hunter and Shaw [29] discuss that a tourist from the southern US vacationing in Costa Rica could see a much reduced (ecological) footprint depending on length of stay. Moreover, as Marzouki et al. [31] found comparing ecological footprints of mass tourism in Tunisia to ecotourism in the Seychelles, this effect depends more on the destination than the type of tourism (mass vs. eco). Thus, it could follow that educational travel program participants who come from countries or regions with high carbon footprints (e.g. due to local power grids that run on coal or oil, high levels of individual car use, poor public transportation etc.) may experience a reduction in their personal carbon footprints despite long-distance flights to their destination. However, this logic also applies in reverse: students from low footprint countries who go to study in high footprint countries like the US would likely see increases in their own carbon footprints. As Figure 1 demonstrates, there are many students who likely fit this bill. Moreover, students' individual behaviors in the educational travel destination, as well as their length of stay can affect their net carbon footprints. As Barr et al. [32] point out, the tourist mindset often overrides pro-environmental behaviors that an individual would employ at home. Thus, it is important for program staff to engage students in this issue and have them reflect on what kind of environmental behaviors make sense away from home. Lastly, a recent study [33] found that educational travel may also encourage visits from family and friends to the student in the travel destination, which also could be seen as increasing the footprint of the participant and program. Ultimately, we must assume that educational travel programs have significant carbon footprints that must be addressed.

\section{It is Not Just Climate Change}

Interest in the impacts of educational travel programs beyond those of global climate change is starting to develop. Schroeder et al. [14] interviewed various stakeholders involved in short-term educational travel programs and found many had not considered negative impacts from the program. My colleagues and I had similar findings when surveying educational travel program leaders and faculty about sustainability in their programs: many did not think about sustainability in their own programs and when they did, they were often limited by institutional or budgetary constraints [34]. Lyons et al. [35] raised concerns about the potential impacts of gap-year and volunteer programs specifically on host communities and highlight that research is needed to better understand this aspect of these programs. Jorgenson [22] explored issues associated with the elitism of educational travel and its perpetration of "colonial" mindsets. Her research further highlights the need for intentional design and execution of these programs to ensure global citizenship outcomes that are not rooted in a purely Western way of perceiving the world.

A recent study I completed examined the potential for environmental and social impacts from educational travel programs on their host destination (specifically in Iceland) [13]. The study collected data from educational travel programs visiting the Westfjords of Iceland and analyzed the sites they visited within a geographic information system (GIS). Using measures of site ecological sensitivity to 
trampling and distance from roads, I found that educational travel programs tend to visit areas that are moderately sensitive to disruption and somewhat removed from human activity. Further, the study also developed an index using the frontstage-backstage continuum (sensu Maccannell [36]) that measured a site's suitability for tourist visits and found that educational travel programs often ventured into backstage areas (i.e. less suitable for tourism), an incursion that is not considered sustainable [37]. Comparing these findings with a similar study on general tourists in the Westfjords [38], I found that educational travel programs tend to go to sites that are more sensitive, both ecologically and socially. As I discussed in the study, these results make sense as educational travel programs tend to bring students to sites that provide good insights into local cultures and ecosystems. Nonetheless, this also means that impacts from educational travel programs are likely not insignificant, particularly when considering that educational travel generally means sizable groups of students rather than individual tourists. For me, these results highlighted the need for universities to support program staff to be able to research destinations adequately to understand current local issues and challenges with respect to sustainability in all its forms (i.e. economic, environmental, and sociocultural). In higher education, we focus a lot (understandably) on learning outcomes. However, should we not also examine our other outcomes? Universities often want to be seen as good citizens in their local communities (the town-gown relationship). Perhaps we should, as I proposed in the study, view host destinations as an extension of the town-gown relationship? No matter the perspective, we owe it to the communities that host us and provide important settings for our programs to make sure that we leave only positive traces.

\section{Leveraging Student Learning to Make Educational Travel Sustainable}

To deal with the negative impacts from educational travel programs and to reap the maximum gains from educational travel experiences for students, universities and faculty need to be intentional about program planning and execution. Designing programs to be more sustainable across the board in terms of culture, economics, environment, and society represents an important first step. This is not simply because it parallels many universities' efforts to green their campuses, but it is also an important part of the education process for students to have their schools practice what they preach [39,40]. Lutterman-Aguilar and Gingerich [16] describe ten characteristics of an experiential educational travel program that include developing a community among students and with the local community, providing opportunities for critical analysis and reflection, and connecting curriculum with local problems. Additionally, as discussed earlier, incorporating active learning opportunities and student research into these programs where possible can also enhance learning outcomes. Service projects and volunteer work may also be useful experiences, when properly and intenionally planned and executed [41].

In a previous examination of educational travel programs at my home institution, my co-author and I examined approaches faculty use to make their program more sustainable [42]. For example, the choice of destination should be explicit and connect with sustainability. Iceland, the setting of my research and one of my own educational travel destinations, highlights both sustainable practices, such as Iceland's use of geothermal and hydrological energy sources, as well as challenges such as tourism pressures and waste management. The mode of traveling to the destination is also an important choice; some programs at my university choose to use trains or buses to get to destinations on the European continent, rather than opt for flights. In the case of Iceland, where a flight is necessary for a short-term visit (the other option is a ferry that requires several days each direction), we chose a route that involves only one flight and use trains or buses to get to/from the departure airport. Lastly, lodging, meals, and activities should be sourced using locally-based providers and ideally ones that are certified for sustainable practices (e.g. the Nordic Swan ecolabel, Qualmark, EarthCheck).

Creating a $100 \%$ sustainable program may not be possible due to lack of faculty and staff awareness or interest, lack of institutional support, or budgetary policies/limitations $[14,34,42]$. However, these are excellent opportunities to engage students. For example, institutional budget policies may prevent 
faculty from purchasing carbon offsets for an educational travel. Instead, the professor could engage the class in the purchase of carbon offsets with personal funds (with opportunities to research and discuss what carbon offsets are, the ethics behind purchasing offsets, and the selection of the offset provider) or have the class develop alternatives (discussed further in next section). A similar type of engagement is also possible for pre-determined sustainable logistic choices. For example, students may balk at flying out of a more distant airport that allows direct flights to the destination but requires a long bus or train ride. Nonetheless the choice is something the class can examine and analyze. A follow-up assignment could have students redesign an educational travel (even if only hypothetically) to make it (more) sustainable. In the next section, I share insights from two assignments that I have used on my own educational travels.

\section{The Footprints We Leave Behind}

Educational travel is embedded in the curriculum of my home institution in the form of a semester course that incorporates at short-term travel experience (10-12 days) in the middle of the semester; students are required to take several of them to obtain their degrees. These academic travels are one of the reasons I became interested in the relationship between educational travel and sustainability. They have also allowed me to accumulate meaningful experience in the field and classroom. One of the travels I have offered most often has used Iceland as its destination. The class has taken several different forms over the years, but has always been an environmental studies course that looks at issues of sustainability and environment. Although targeted at students majoring in environmental studies or sciences, the course is generally open to students in any discipline. Iceland, which as mentioned above and elsewhere [42], presents the students with great examples of sustainable energy use and the challenges of a rapid increase in tourism combined with limited infrastructure. When I originally developed the course in 2009, I intentionally decided to showcase sustainability practices in the course logistics (see above), which I share with and discuss with the students. For the first half of the course, prior to the actual travel, we typically spend time learning background about the environmental issues we will experience in situ as well as the Icelandic setting. In the field, students meet with local stakeholders in various environmental sectors (e.g. scholars, engineers, government officials, writers, businesspeople), engage in research projects to examine environmental impacts firsthand, and take excursions to see relevant sites. Among the assignments I have used are a personal environmental audit adapted from Savageau [43] and a carbon offset assignment inspired by Dvorak et al. [12].

I adapted the personal audit assignment from a course module developed Savageau [43] (NB: The Savageau article provides a useful framework and examples for adaptations). The assignment required students to collect data on their personal consumption habits for several days on campus and during the travel portion of the course. The students then compiled the data and wrote a paper interpreting their findings and reflecting on what the results said about how and why consumption patterns may differ when we travel. I often have asked students to use an online footprint calculator (e.g. http://www.footprintcalculator.org) to supplement their results and place their findings within a societal context. Generally, the students struggle with the assignment and sometimes complain about the onus of collecting data on their own practices. Nonetheless, judging from the final project, the audit seems to have been a successful tool to engage students with environmental issues connected to lifestyles and travel. As Savageau found with her own students, the project seemed to allow students to reflect on aspects of their lifestyles they may not have thought about before and helped them identify ways that they can effect change in their own lives. Table 1 presents several quotes from the final student papers where they were asked to reflect on the societal relevance of the project. To select these quotes, I examined papers from the course offered in 2015 in groups (based on students' declared fields of study/major) and chose the first paper from each group in which the student reflected explicitly on benefits of the project for her or himself (NB: The course had 24 students). 
Table 1. Selected student quotes from the final personal ecological audit report.

\begin{tabular}{cc}
\hline Student's Major & Student Reflections \\
\hline Communications & $\begin{array}{r}\text { [B]eing conscious of differences in the personal energy and water } \\
\text { consumption as well as waste generation behavior while at home and } \\
\text { traveling can help us adjust to the surroundings so that to minimize our } \\
\text { footprint. Such consciousness will help us choose most sustainable travel } \\
\text { options and behaviors that would help us enjoy the new experiences } \\
\text { without harming the environment. }\end{array}$ \\
Economics & $\begin{array}{r}\text { This is the first trip that I have given thought to monitoring my } \\
\text { consumption of goods and energy away from my home. }\end{array}$ \\
\hline Environmental studies & $\begin{array}{r}\text { [The audit] makes me realize that I am responsible both as a tourist and a } \\
\text { university student to try to minimize my ecological effects. }\end{array}$ \\
[The audit] has led to numerous changes in my daily behavior, changes that \\
aim to decrease my ecological footprint: I'm now vegetarian, I don't flush \\
every single time I use the toilet, I shower quicker, and I make sure to only \\
turn on the lights when I need them.
\end{tabular}

The second assignment I have started using is one involving carbon offsets (I have only used it once thus far). I have bought carbon offsets for this course since the first year I offered it to demonstrate to students that we should not simply fly and either ignore our emissions or choose to write off our carbon emissions to educational benefits. Nonetheless, this "simplistic" solution always has always bothered me. Upon reading Dvorak et al.'s [12] own struggles with the approach of buying offsets and the solution of some of their students to create their own offsets, I decided to create an assignment where students not only calculate our program's carbon footprint (and their part of it), but also where they analyze their lifestyles and propose changes in their daily lives that would offset an equivalent amount of greenhouse gases; these offsets were to complement the third-party offsets I typically buy. The learning outcome ended up being greater for me than the students, as I discovered that many students did not realize what activities in their own lives generate greenhouse gas emissions (side note: about half of the students did not have any previous environmental science coursework). Some students proposed changes in their lives that did not connect directly with reducing greenhouse gas emissions (e.g. flushing the toilet less frequently, recycling their plastic bottles, or eating organic food). Thus, it was obvious, these students were unable to understand the difference between behaviors that have environmental benefits and those that specifically target greenhouse gas emissions. In the end, I decided to backtrack and allow more time to discuss greenhouse gases with the class, so they could better understand the general concept of offsets. I look forward to the next chance to offer this assignment in an upcoming semester.

In regard to the success of the entire course/travel experience, I have generally received positive feedback that supports the research on student learning outcomes from educational travel, be it formal feedback on the course in student reflective essays and end-of-semester course evaluations, or informal feedback that I get from students in the semesters and years since they have taken the course. In Table 2, I provide comments from a formal reflective essay that students completed at the end of the course in 2014 (NB: As above, this course had 24 students). I selected quotes that represented the range of comments across different majors and different impressions. The experience seemed to have been transformational for many, both environmental studies majors and others. Students reported wanting to change their consumption and traveling habits beyond this course. Some reported being made uncomfortable by some experiences (e.g. the "overcrowding" at tourist sites mentioned in the economics student in Table 2) but recognized the value in that discomfort. Several also connected their experiences from travel with their home contexts. It is important to note that this was a graded assignment and as such students may have been unwilling to critique their experiences. 
Table 2. Selected exemplary comments from students' reflective papers on the course.

\begin{tabular}{|c|c|}
\hline Student's major & Student comments \\
\hline Environmental studies & $\begin{array}{l}\text { I think I will forever more be more mindful of where I am stepping, on or off } \\
\text { trail. }\end{array}$ \\
\hline International Relations & $\begin{array}{l}\text { I had never traveled with a focus on sustainability like we did on this } \\
\text { particular [course] so the experience was very eye opening ... I will } \\
\text { definitely implement more sustainable travel into my future plans. }\end{array}$ \\
\hline Management & $\begin{array}{c}\text { My experience of traveling sustainably has immensely shifted the way in } \\
\text { which I would go about traveling in the future ... The [course] certainly did } \\
\text { change my perception of eco-tourism and is something I will enforce on my } \\
\text { future travels too. }\end{array}$ \\
\hline Environmental studies & $\begin{array}{c}\text { This [course] has helped me change my perception of what it means to be a } \\
\text { sustainable traveler ... I understand now that not only the physical } \\
\text { environment needs to be looked at but also the economic and socio-cultural } \\
\text { environment aspects. }\end{array}$ \\
\hline Economics & $\begin{array}{c}\text { While I didn't enjoy this time seeing the large crowds and their side-effects } \\
\text { on the environment and culture, these visits complemented our discussions } \\
\text { well and brought together the theme of our course and enriched my } \\
\text { understanding of environmental issues. }\end{array}$ \\
\hline International Relations & $\begin{array}{c}\text { Being in Iceland raised my awareness on environmental issues not only in } \\
\text { Iceland, but especially in my own country. }\end{array}$ \\
\hline
\end{tabular}

\section{Concluding Thoughts}

Educational travel in its many varied forms offers powerful learning opportunities for students. Nonetheless, these opportunities can come with a price that we often (hopefully unintentionally) have pushed off onto host communities and regions. In the discussion of a recent study [13] on the impacts of educational travel programs, I laid out several approaches to improve the implementation of sustainable educational travel in higher education. I synthesize those approaches here with the ideas presented above as a roadmap for institutions, programs, and staff (summarized in Figure 2).

- First, the proper foundation for sustainable programs must be laid by the institutions (i.e. universities and third-party providers), which need to provide support and encouragement from the highest levels. The goal should strive for sustainability across the board-economic, environmental, and socio-cultural and the lowest possible impacts on host destinations and the global environment. Perhaps most importantly, the institutions need to embed sustainable goals in their missions and modes of operation. They should also revise budgeting procedures and policies to permit sustainable logistics and travel, even when they cost more. If this increases program costs, then scholarships or other forms of financial aid should be made available to participants so that educational travel remains open to individuals across the socioeconomic spectrum.

- Second, institutions need to ensure that program faculty and staff have the appropriate background, training, and professional development opportunities. Program staff need to possess an adequate level of sustainable literacy, know how to incorporate sustainable principles into program logistics and curricula, and be familiar with their destinations and the issues and challenges the destinations face. Program staff also need to develop good relationships with host communities that will support educational objectives for sustainability. As Lutterman-Aguilar and Gingerich [16] wrote: "[faculty] have a responsibility to work collaboratively with the local community to ensure that their relationships are built on mutuality and reciprocity and not on any kind of exploitation (70)."

- Third, institutions and program staff need to be deliberate in their design and development of new programs, as well as the redesign of existing ones. This includes choosing (or revising) destinations that offer a suitable setting for a sustainable program and designing the program to avoid regions and seasons that may not allow for the execution of a sustainable program. This also 
means developing a focus that lends itself to education about (aspects of) sustainability, regardless of the discipline.

- Fourth, programs need to adapt pedagogical approaches that are effective at teaching students not just about the topic at hand, but also the host destination (culture and environment) and what it means to be a sustainable global citizen. Multiple frameworks already exist that educators can draw upon: experiential education [16], Leave No Trace [44], transformative learning theory [21], and Value-Belief-Norm theory [18], to name a few. Incorporating active learning and high impact educational approaches, such as student research experiences, will further support the learning gains.

- Fifth, it goes almost without saying that programs need to be designed with logistics that strive for sustainability. In a world where the impacts of unmitigated climate change will likely be catastrophic, the inevitable greenhouse gas emissions from travel must be limited through the choices of climate-friendly modes of travel and behaviors. Further, food and lodging in the programs should also reflect sustainable principles that benefit local economies, societies, and environments. The same should apply to a program's activities (e.g. field trips, cultural events, etc.)

- Lastly, programs will inevitably generate some negative impacts and programs should strive to offset those impacts as much as possible, ideally engaging the students in the process. With respect to greenhouse gas emissions, a program might buy carbon offsets, develops its own offsets, find other ways to make the educational experience worth the carbon cost, or combine all three approaches. Well-planned service projects, volunteer work, and applied research, when done in tandem with reputable organizations in the host community, can also provide important benefits for the community. Additionally, as García and Longo [41] describe, "[w]hen done well ... service-learning can be a tool for higher education programs to educate the next generation of engaged citizens (119)."

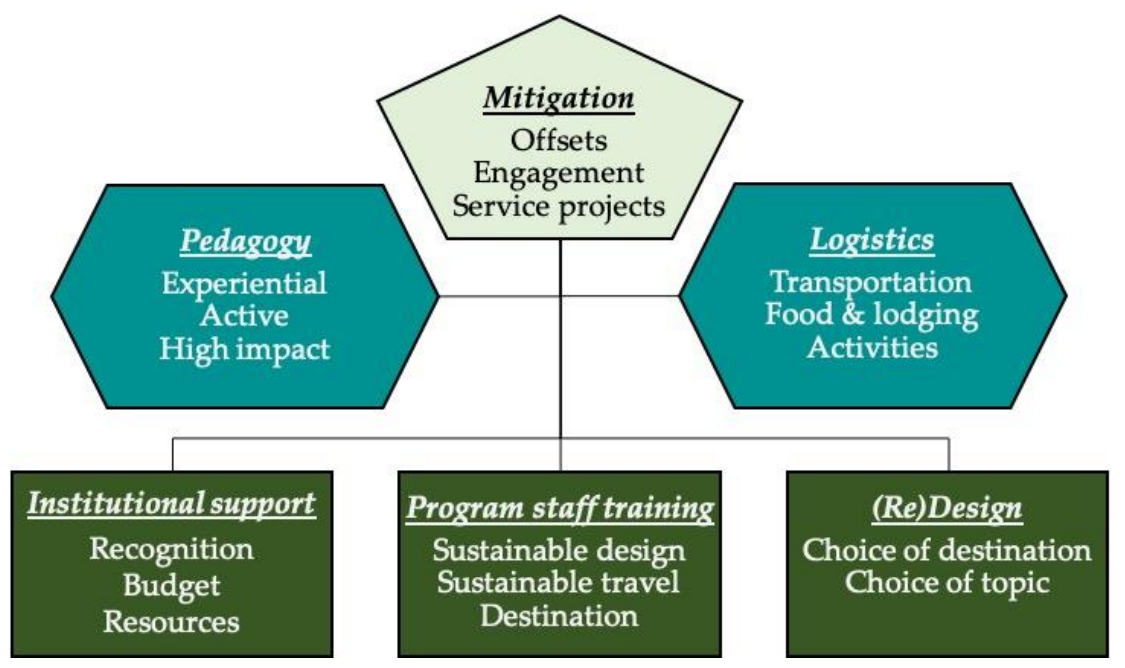

Figure 2. Overview of necessary elements for more sustainable educational travel programs.

Ultimately, educational travel is needed in today's world. Experiencing other cultures, lifestyles, and environments helps to create global citizens that will be important members of tomorrow's society. However, we need to make sure we see the forest for the trees and make educational travel sustainable for all who play a role in making it happen.

Funding: This research was funded in part by the Swiss National Science Foundation (IZK0Z2_171645) and by Franklin University Switzerland's Faculty Development Funds.

Acknowledgments: The author graciously thanks Q. Duroy for the invitation to contribute to this issue; his previous collaborators, A. Vogelaar and J. Long, for their encouragement; P. Weiss and his colleagues in the 
Westfjords for their support during the field research cited herein; L. Mundy-Shaw for his able research assistance; and A. Gardiner and S. Steinert-Borella for their comments on previous draft. Any remaining errors are my own.

Conflicts of Interest: The author is an educational travel leader in addition to an educational travel researcher and declares no further conflicts of interest.

\section{Appendix A}

I estimated the carbon dioxide emissions from educational travel by using the number of international undergraduates in the US and the number of US students studying abroad from the Open Doors regional factsheets for 2018 [25]. I used Chicago as the US city of departure/arrival due to its central location in the US and selected a major city in each region (Table A1). For each region, I chose a departure city for inbound students based on the country that sends the greatest number of students (NB: for Europe, since the UK, Germany, and Turkey send similar numbers of students, I chose Berlin as a middle point). For outbound students, I chose a major city in the most common destination country (NB: for Europe, since the UK, France, and Italy receive similar numbers of US students, I chose Paris as a middle point). I estimated the emissions per student as the amount of carbon dioxide emitted in one roundtrip between Chicago and the region's selected city using myclimate's [45] online calculator. Not surprisingly, students coming from/going to Oceania have the highest individual footprints, as Oceania is the furthest from the US.

As Figure 1 shows, the estimate for the total emissions from 2018 is approximately 2.5 million tonnes of $\mathrm{CO}_{2}$. The largest contributor for inbound students to the US (and overall) is Asia, while the largest contributor for outbound US students are programs to Europe. Due to much smaller numbers of participants, the footprint of programs to and from Oceania are low, despite the large individual emissions.

Table A1. Assumed departure/arrival destinations for 2018 educational travel participants and the relate carbon dioxide emissions of one-roundtrip to/from Chicago.

\begin{tabular}{ccccc}
\hline Region & \multicolumn{2}{c}{ Inbound } & \multicolumn{2}{c}{ Outbound } \\
\hline & Departure & tonnes $\mathrm{CO}_{2}$ & Arrival & tonnes $\mathrm{CO}_{2}$ \\
\hline Asia & Beijing & 4.1 & Beijing & 4.1 \\
\hline Europe & Berlin & 2.6 & Paris & 2.5 \\
\hline Latin America & Rio de Janeiro & 3.2 & San Jose & 1.4 \\
\hline Mid. East/N. Africa & Riyadh & 4.4 & Tel Aviv & 3.8 \\
\hline Oceania & Melbourne & 6.4 & Melbourne & 6.4 \\
\hline Sub-Saharan Africa & Lagos & 3.7 & Johannesburg & 5.7 \\
\hline
\end{tabular}

\section{References}

1. Larrington, C. The Poetic Edda; Oxford University Press: Oxford, UK, 1996; ISBN 0192839462.

2. Paige, R.M.; Fry, G.W.; Stallman, E.M.; Josić, J.; Jon, J. Study abroad for global engagement: The long-term impact of mobility experiences. Intercult. Educ. 2009, 20, S29-S44. [CrossRef]

3. Rexisen, R.J. The impact of study abroad on the development of pro-environmental attitudes. Int. J. Sustain. Educ. 2013, 9, 7-19. [CrossRef]

4. Murphy, D.; Sahakyan, N.; Yong-Yi, D.; Magnan, S.S. The impact of study abroad on the global engagement of university graduates. Front. Interdiscip. J. Study Abroad 2014, 24, 1-24.

5. Engberg, M.E. The Influence of Study Away Experiences on Global Perspective-Taking. J. Coll. Stud. Dev. 2013, 54, 466-480. [CrossRef]

6. Stoner, K.R.; Tarrant, M.A.; Perry, L.; Stoner, L.; Wearing, S.; Lyons, K. Global citizenship as a learning outcome of educational travel. J. Teach. Travel Tour. 2014, 14, 149-163. [CrossRef] 
7. Bell, H.L.; Gibson, H.J.; Tarrant, M.A.; Perry, L.G.; Stoner, L. Transformational learning through study abroad: US students' reflections on learning about sustainability in the South Pacific. Leis. Stud. 2016, 35, 389-405. [CrossRef]

8. McLaughlin, J.; Patel, M.; Johnson, D.K.; de la Rosa, C.L. The Impact of a Short-Term Study Abroad Program that Offers a Course-Based Undergraduate Research Experience and Conservation Activities. Front. Interdiscip. J. Study Abroad 2018, 30, 100-118.

9. Landon, A.M.; Woosnam, K.; Keith, S.; Tarrant, M.; Rubin, D.T.; Ling, S. Understanding and modifying beliefs about climate change through educational travel. J. Sustain. Tour. 2019, 27, 292-307. [CrossRef]

10. Miles, J. For the love of Earth, stop traveling, Washington Post, $2017 . \quad$ Available online: http://aireform.com/wp-content/uploads/20171102..--For-the-love-of-Earth-stop-traveling-J.MilesOpinion-in-WashingtonPost-26p-w-comments.pdf (accessed on 28 May 2019).

11. Welin, M. Green Swedes Shun Holiday Flights for Lure of the Train. Available online: https://www.bbc.com/ news/world-europe-47805990 (accessed on 9 April 2019).

12. Dvorak, A.; Christiansen, L.; Fischer, N.L.; Underhill, J.B. A Necessary Partnership: Study Abroad and Sustainability in Higher Education. Front. Interdiscip. J. Study Abroad 2011, 21, 143-166.

13. Hale, B.W. Understanding potential impacts from university-led educational travel. Int. J. Sustain. High. Educ. 2019, in press. [CrossRef]

14. Schroeder, K.; Wood, C.; Galiardi, S.; Koehn, J. First, do no harm: Ideas for mitigating negative community impacts of short-term study abroad. J. Geogr. 2009, 108, 141-147. [CrossRef]

15. Long, J.; Vogelaar, A.; Hale, B.W. Toward sustainable educational travel. J. Sustain. Tour. 2014, 22, 421-439. [CrossRef]

16. Lutterman-Aguilar, A.; Gingerich, O. Experiential pedagogy for study abroad: Educating for global citizenship. Front. Interdiscip. J. Study Abroad 2002, 8, 41-82.

17. Grabowski, S.; Wearing, S.; Lyons, K.; Tarrant, M.; Landon, A. A rite of passage? Exploring youth transformation and global citizenry in the study abroad experience. Tour. Recreat. Res. 2017, 42, 139-149. [CrossRef]

18. Tarrant, M.A. A Conceptual Framework for Exploring the Role of Studies Abroad in Nurturing Global Citizenship. J. Stud. Int. Educ. 2009, 14, 433-451. [CrossRef]

19. Kilgo, C.A.; Sheets, J.K.E.; Pascarella, E.T. The link between high-impact practices and student learning: Some longitudinal evidence. High. Educ. 2015, 69, 509-525. [CrossRef]

20. Wynveen, C.J.; Kyle, G.T.; Tarrant, M.A. Study Abroad Experiences and Global Citizenship: Fostering Proenvironmental Behavior. J. Stud. Int. Educ. 2011, 16, 334-352. [CrossRef]

21. Strange, H.; Gibson, H.J. An investigation of experiential and transformative learning in study abroad programs. Front. Interdiscip. J. Study Abroad 2017, 29, 85-100.

22. Jorgenson, S. De-centering and re-visioning global citizenship education abroad programs. Int. J. Dev. Educ. Glob. Learn. 2010, 3, 23-38. [CrossRef]

23. Masson-Delmotte, V.; Zhai, P.; Pörtner, H.-O.; Roberts, D.; Skea, J.; Shukla, P.R.; Pirani, A.; Moufouma-Okia, W.; Péan, C.; Pidcock, R.; et al. Global warming of $1.5^{\circ} \mathrm{C}$. an IPCC special report on the impacts of global warming of $1.5^{\circ} \mathrm{C}$ above pre-industrial levels and related global greenhouse gas emission pathways, in the context of strengthening the global response to the threat of climate change. In Proceedings of the Third Lead Author Meeting, Cairns, Australia, 9 April 2018.

24. World Meteorological Organization WMO Statement on the State of the Global Climate in 2018; World Meteorological Organization: Geneva, Switzerland, 2019.

25. Institute of International Education Data by Region Fact Sheets. Available online: https://www.iie.org/ Research-and-Insights/Open-Doors/Fact-Sheets-and-Infographics/Data-by-Region-Fact-Sheets (accessed on 13 April 2019).

26. Carbon Dioxide Information Analysis Center Oak Ridge National Laboratory World Bank Open Data. Available online: https://data.worldbank.org (accessed on 11 April 2019).

27. Brouwer, R.; Brander, L.; Beukering, P. "A Convenient Truth": Air Travel Passengers' Willingness to Pay to Offset Their $\mathrm{CO}_{2}$ Emissions. Clim. Chang 2008, 90, 299-313. [CrossRef]

28. Gössling, S.; Broderick, J.; Upham, P.; Ceron, J.-P.; Dubois, G.; Peeters, P.; Strasdas, W. Voluntary Carbon Offsetting Schemes for Aviation: Efficiency, Credibility and Sustainable Tourism. J. Sustain. Tour. 2007, 15, 223-248. [CrossRef] 
29. Hunter, C.; Shaw, J. The ecological footprint as a key indicator of sustainable tourism. Tour. Manag. 2007, 28, 46-57. [CrossRef]

30. Patterson, T.M.; Niccolucci, V.; Bastianoni, S. Beyond "more is better": Ecological footprint accounting for tourism and consumption in Val di Merse, Italy. Ecol. Econ. 2007, 62, 747-756. [CrossRef]

31. Marzouki, M.; Froger, G.; Ballet, J. Ecotourism versus mass tourism. A comparison of environmental impacts based on ecological footprint analysis. Sustainability 2012, 4, 123-140. [CrossRef]

32. Barr, S.; Shaw, G.; Coles, T.; Prillwitz, J. 'A holiday is a holiday': Practicing sustainability, home and away. J. Transp. Geogr. 2010, 18, 474-481. [CrossRef]

33. Davies, J.C.; Dunk, R.M. Flying along the supply chain: Accounting for emissions from student air travel in the higher education sector. Carbon Manag. 2015, 6, 233-246. [CrossRef]

34. Hale, B.W.; Vogelaar, A.E.; Long, J. A-Broad Spectrum: Sustainability in educational travel. Int. J. Sustain. High. Educ. 2013, 14, 349-366. [CrossRef]

35. Lyons, K.; Hanley, J.; Wearing, S.; Neil, J. Gap year volunteer tourism: Myths of global citizenship? Ann. Tour. Res. 2012, 39, 361-378. [CrossRef]

36. Maccannell, D. The Tourist: A New Theory of the Leisure Class, 1st ed.; Schocken Books: New York, NY, USA, 1976.

37. Weaver, D. Sustainable Tourism: Theory and Practice, 1st ed.; Butterworth Heinemann: Burlington, MA, USA, 2006.

38. Hale, B.W. Mapping Potential Environmental Impacts from Tourists Using Data from Social Media: A Case Study in the Westfjords of Iceland. Environ. Manag. 2018, 62, 446-457. [CrossRef]

39. Leal Filho, W.; Raath, S.; Lazzarini, B.; Vargas, V.R.R.; de Souza, L.; Anholon, R.; Quelhas, O.L.G.L.G.; Haddad, R.; Klavins, M.; Orlovic, L.V. The Role of Transformation in Learning and Education for Sustainability. J. Clean. Prod. 2018, 199, 286-295. [CrossRef]

40. Sjerps-Jones, H. Engaging students with sustainability issues. Planet 2007, 18, 40-42. [CrossRef]

41. García, N.A.; Longo, N.V. Going Global: Re-Framing Service-Learning in an Interconnected World. J. High. Educ. Outreach Engagem. 2013, 17, 111-135.

42. Hale, B.W.; Vogelaar, A. The Road Less (Sustainably) Traveled: A Case Study of Academic Travel at Franklin University Switzerland. In Integrating Sustainability Thinking in Science and Engineering Curricula; Leal Filho, W., Ed.; Springer International: Cham, Switzerland, 2015; pp. 183-195.

43. Savageau, A.E. Let's get personal: Making sustainability tangible to students. Int. J. Sustain. High. Educ. 2013, 14, 15-24. [CrossRef]

44. The Leave No Trace Center for Outdoor Ethics. The Leave No Trace Seven Principles. Available online: https://lnt.org/learn/7-principles (accessed on 18 October 2017).

45. Myclimate. Offset Your Flight Emissions! Available online: https://co2.myclimate.org/en/flight_calculators/ new. (accessed on 10 April 2019). 